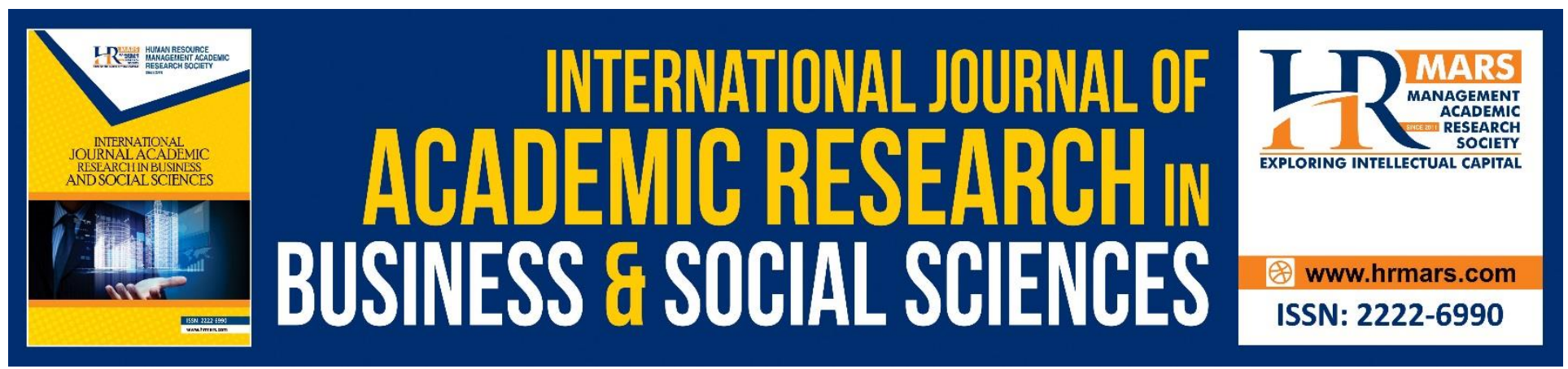

\title{
Relationship between Leadership of the Board with the Effectiveness of Farmers Group
}

\section{Achdiyat, Dyah Gandasari}

To Link this Article: http://dx.doi.org/10.6007/IJARBSS/v8-i7/4400

DOI: $10.6007 /$ IJARBSS/v8-i7/4400

Received: 20 May 2018, Revised: 23 June 2018, Accepted: 29 June 2018

Published Online: 18 July 2018

In-Text Citation: (Achdiyat, 2018)

To Cite this Article: Achdiyat, D. G. (2018). Relationship between Leadership of the Board with the Effectiveness of Farmers Group. International Journal of Academic Research in Business and Social Sciences, 8(7), 573582.

Copyright: (c) 2018 The Author(s)

Published by Human Resource Management Academic Research Society (www.hrmars.com)

This article is published under the Creative Commons Attribution (CC BY 4.0) license. Anyone may reproduce, distribute, translate and create derivative works of this article (for both commercial and non-commercial purposes), subject to full attribution to the original publication and authors. The full terms of this license may be seen

at: http://creativecommons.org/licences/by/4.0/legalcode

Vol. 8, No. 7, July 2018, Pg. 573 - 582

http://hrmars.com/index.php/pages/detail/IJARBSS

JOURNAL HOMEPAGE

Full Terms \& Conditions of access and use can be found at http://hrmars.com/index.php/pages/detail/publication-ethics 


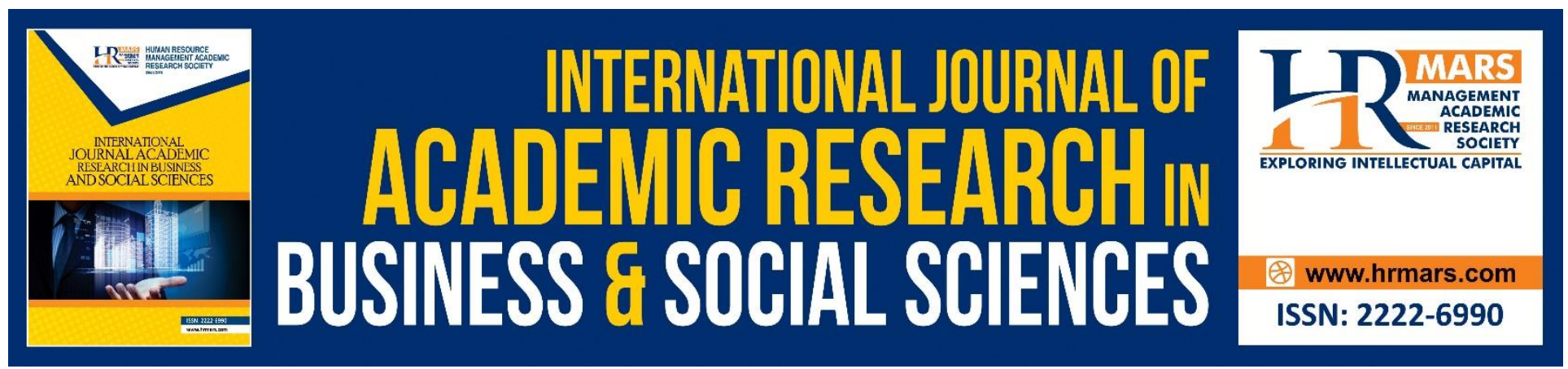

\title{
Relationship between Leadership of the Board with the Effectiveness of Farmers Group
}

\author{
Achdiyat, Dyah Gandasari \\ Bogor Agriculture Extension College
}

\begin{abstract}
One important factor for the realization of effective farmer groups is the leadership of the group. The role of leaders is important in finding alternative problem solving to ensure order in a group. So the leadership of the board and its relationship to the effectiveness of farmer groups is important to be studied. The purpose of this study is to know the relationship between leadership of the board with the effectiveness of farmers group in Malingping District, Lebak Regency, Banten Province. The method used in this study is survey and sample design with number source of information of 102 people. The data is analyzed using Rank Spearman correlation and group analysis unit. The results of the study are: 1) there is a relationship between self-confidence and relevant knowledge about work with the effectiveness of farmers group, and 2 ) there is a relationship between task orientation and relationship orientation with the level of the group members' satisfaction.
\end{abstract}

Keywords: Relationship orientation, Task orientation, Satisfaction, Confidence, Knowledge

\section{Introduction}

Efforts to grow farmers groups in Indonesia have been started since the Dutch colonial era until now (Yunasaf, 2007). The growth and development of farmers groups is done through the supervision of farmers groups which is guided to applying agribusiness system, increasing the role, participation of farmers by increasing cooperation between farmers and other related parties in order to increase their farm business (Prasetyo \& Falentino, 2015). Prasetyo and Falentino (2015) further stated that the development of farmers group is expected to help to explore farmers' potentials, solve their problems of farming more effectively, and facilitate farmers in accessing information, markets, technology, capital and other resources.

Until now, farmer group are still used as the main approach in extension activities (Deptan, 2000). The group approach is considered as more efficient and can be a media for learning and experimentation process for farmers, so it is expected to change the behavior of farmers to be better or quality (Margono, 2001). To build qualified farmers, the existing farmers groups must have the power to determine and influence the behavior of groups and its members in achieving the goals effectively.

Study on the farmers group leadership and its relationship to the group effectiveness is important because of the following: 1) the role of leadership is required in ensuring order, compliance 
INTERNATIONAL JOURNAL OF ACADEMIC RESEARCH IN BUSINESS AND SOCIAL SCIENCES

Vol. 8, No. 7, July 2018, E-ISSN: 2222-6990 @ 2018 HRMARS

with rules, norms and policies and reducing conflict; 2) based on the previous studies, there are still problems of farmers group on the group effectiveness.

Some previous studies found that the obstacles faced by farmers group are the following: a) the limited ability of the head of the farmers group to access agricultural production facilities (Prasetya \& Falentino, 2015); b) the existing farmers groups have not shown their effectiveness as expected; c) the function of farmers group as interaction medium has not functioned effectively; $d$ ) lack of leader's role to encourage the group's effectiveness, the leader can not catch the members' aspiration (Yunasaf, 2007); e) the leader is not able to mobilize participation in making the work plan and can not motivate the members (Yunasaf, 1997); f) the low leadership level of the group leader and the low of factors or forces that can encourage the behavior of groups and their members to achieve their goals effectively (Yunasaf, Ginting, Slamet, \& Tjitropranoto, 2008); g) the group has not performed its functions or performance well (Siddiq, 2014); and h) the low participation of the actors in the group (Adong, Mwara \& Okoboi, 2013).

The purpose of this study is to know the relationship between leadership of the board and the effectiveness of farmer groups as an effort to grow the farmer group.

\section{Methodology}

Logical Framework: This study examined the relationship between leadership of the board and group effectiveness, the approach used in assessing leadership in this study is based on the nature and behavior.

The study on the farmers group leadership is based on the aspects of: 1) Nature includes: a) drivers, b) desire to lead, c) honesty and integrity, d) self confidence, e) intelligence, f) job-relevant knowledge, and g) Extraversion (passion); 2) Behavior includes; a) orientation to the task and b) relationships with its members. The group effectiveness includes: a) productivity, b) morale and c) member satisfaction level (Figure 1).

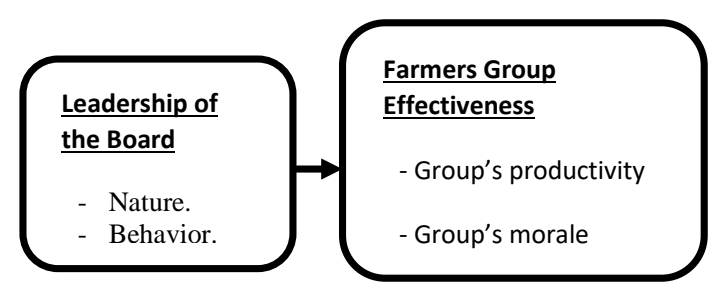

Figure 1. Logical Framework

Based on the logical framework then made the following hypothesis: There is a relationship between board leadership with the group effectiveness.

Method: The study location is determined and restricted to the place where the farmers groups have been join the farmers group association in Lebak Regency. The study location is Bolang Village, Malingping District, Lebak Regency, Banten Province. Site selection is done with the consideration of Lebak is one of the center of the rice production in Banten. The study was conducted from May until December 2017.

This study used survey design and sample with respondent as many as 102 farmers as the source of information. The data is analyzed using Rank Spearman correlation. The unit of analysis in this study is a farmers group. The respondents are active members of the five farmers groups, namely: a) Sri Rahayu I = 21 members; b) Sri Rahayu II = 20 members; c) Sri Mekar Layung $=20$ 
INTERNATIONAL JOURNAL OF ACADEMIC RESEARCH IN BUSINESS AND SOCIAL SCIENCES

Vol. 8, No. 7, July 2018, E-ISSN: 2222-6990 @ 2018 HRMARS

members; 3. Bolang Asih I = 21 members; and 4. Bolang Asih II = 20 members. The farmers groups are associated in Sumber Tani Farmers Groups Association in Bolang Village Lebak Regency of Banten Province.

\section{Results}

\section{Leadership Level Based on Nature}

Table 1 provides the leadership level based on nature.

Table 1: Leadership Level Based on Nature

\begin{tabular}{|c|c|c|c|c|c|c|}
\hline & \multirow{2}{*}{ Nature } & \multicolumn{5}{|c|}{ Category (\%) } \\
\hline & & 1 & 2 & 3 & 4 & 5 \\
\hline 1. & Driver & 3,27 & 25,49 & 60,13 & 10,78 & 0,33 \\
\hline 2. & Desire to lead & 1,96 & 29,41 & 60,13 & 8,17 & 0,33 \\
\hline 3. & $\begin{array}{l}\text { Honesty and } \\
\text { rity }\end{array}$ & 1,80 & 21,90 & 66,99 & 9,15 & 0,16 \\
\hline 4. & Self confidence & 0,65 & 14,71 & 75,16 & 9,48 & 0,00 \\
\hline 5. & Intelligence & 1,96 & 21,57 & 68,95 & 7,52 & 0,00 \\
\hline 6. & $\begin{array}{l}\text { job-relevant } \\
\text { /ledge }\end{array}$ & 0,98 & 27,12 & 64,71 & 7,19 & 0,00 \\
\hline $\begin{array}{r}7 . \\
p\end{array}$ & $\begin{array}{l}\text { Ekstraversion/ } \\
\text { on }\end{array}$ & 0,00 & 31,44 & 59,53 & 8,70 & 0,33 \\
\hline
\end{tabular}

Remark: 1. Very Low, 2. Low, 3. Intermediate, 4. High, 5. Very High

Table 1 shows the leadership level based on nature consist of driver, desire to lead, honesty and integrity, self confidence, intelligence, job-relevant knowledge, ekstraversion/passion and there are 5 categories of Likert's: very low, low, intermediate, high and very high.

\section{Level of Leadership Based on Behavior}

Table 2: Leadership Level Based on Behavior

\begin{tabular}{lccccc}
\hline Behavior & \multicolumn{5}{c}{ Category } \\
\cline { 2 - 6 } & 1 & 2 & 3 & 4 & 5 \\
\hline 1. Orienta & 7.0 & 26. & 45. & 19. & 0.5 \\
tion to & 6 & 76 & 89 & 74 & 4 \\
the task & & & & & \\
2. Orienta & 3.0 & 27. & 53. & 15. & 0.4 \\
tion to & 6 & 82 & 25 & 44 & 4 \\
relation & & & & & \\
ship & & & & & \\
\hline
\end{tabular}

Remark: 1. Not dominant, 2. Rather dominant, 3. Normal, 4. Dominant, 5. Very dominant

Table 2 shows the leadership level based on behavior consist of orientation to the task and orientation to relationship and there are 5 categories of Likert's: not dominant, rather dominant, normal, dominant and very dominant. 


\section{Analysis of the Relationship between Leadership with Group Effectiveness}

The study analyzed the relationship between leadership by nature with group effectiveness ie group productivity, group morale and member satisfaction level (Table 3) and the relationship between behavioral leadership and group effectiveness (group productivity, group morale and member satisfaction level) (Table 4).

Table 3. Relationship between leadership by nature with farmers group effectiveness

\begin{tabular}{|c|c|c|c|}
\hline \multirow[b]{2}{*}{ Leadership by nature } & \multicolumn{3}{|c|}{ Farmers Group Effectiveness } \\
\hline & $\begin{array}{l}\text { Group } \\
\text { Productivity }\end{array}$ & $\begin{array}{l}\text { Group } \\
\text { Morale }\end{array}$ & $\begin{array}{l}\text { Member } \\
\text { satisfac-tion } \\
\text { level }\end{array}$ \\
\hline \multicolumn{4}{|l|}{ Drive } \\
\hline & 0.093 & -0.021 & 0.008 \\
\hline Desire to lead & -0.048 & 0.053 & -0.008 \\
\hline Honesty and integrity & 0.008 & 0.126 & 0.070 \\
\hline Self confidence & $0.236^{*}$ & 0.126 & 0.142 \\
\hline \multicolumn{4}{|l|}{ Intelligence } \\
\hline & -0.157 & -0.040 & -0.171 \\
\hline Job relevant knowledge & $0.227^{*}$ & 0.154 & 0.012 \\
\hline Extraversion & -0.098 & 0.082 & 0.129 \\
\hline
\end{tabular}

Remark: * significantly correlated at $p<0.05$ and ** very significantly correlated at $p<0.01$

Table 3 shows that the results of Spearman's correlation test indicating there is a relationship between self-confidence with the effectiveness of the group. 
INTERNATIONAL JOURNAL OF ACADEMIC RESEARCH IN BUSINESS AND SOCIAL SCIENCES

Vol. 8, No. 7, July 2018, E-ISSN: 2222-6990 @ 2018 HRMARS

Table 4: Relationship between behavioral leadership and group effectiveness

Farmers Group Effectiveness

\begin{tabular}{|c|c|c|c|}
\hline & & & \\
\hline Leadership by behavior & Group Productivity & Group Morale & $\begin{array}{l}\text { Member } \\
\text { satisfac-tion } \\
\text { level }\end{array}$ \\
\hline
\end{tabular}

Orientation to task

$0.006 \quad 0.110 \quad 0.236^{*}$

Orientation to

relationship

0.129

0.145

$0.335^{* *}$

Table 4 Spearman correlation test results shows that there is a relationship between orientation to task with the effectiveness of the farmers' group.

\section{Discussion}

\section{Leadership based on Nature and Behavior}

Leadership by nature is a judgment that shows the ability of a farmers' group board in leadership by virtue of the traits he normally does in leading. Leadership within a farmers' group is volunteer leadership based on the choice of members. According to Miller (2008) one of the lessons we have received is someone becomes leader because others ask him to lead. Therefore, many of the farmers do not understand the potential of leadership they have. Miller (2008) stated that generally leaders do not understand the leadership skills and potential they have when leading. Based on the study result, the leadership level of farmers' group is shown in Table 1 and Table 2.

Table 1 shows that by its nature, the leadership level of the farmers group is intermediate with a percentage of $59.53-75.16$ percent. The intermediate level of leadership is indicated from the limited ability of the farmers in mobilizing the members to do the activities, the lack of desire to lead, the spirit to advance the group, and the lack of confidence. The intermediate leadership is caused by inadequate leadership knowledge in management and communication. The inadequate management knowledge is related to the skill in managing members. The inadequate communication knowledge is related to the low self-confidence. The confidence is one of the factors that influence in the effectiveness of communicating. According to Mubarok and Priatna (2016) a leader needs to have communication skills.

Leadership based on behavior indicates the leader's orientation in leading its members. The intended leader orientation is the leader's orientation towards group task completion or humanist relationships to its members. Table 2 shows the distribution of leadership behavior of Farmers Contact Person based on respondents' statement.

Table 2 shows the leadership value of the farmers group based on the orientation to the tasks included in the normal/enough category with a percentage of $45.89 \%$. The values include the following behaviors: the ability to explain what the member hopes for, the ability to explain the idea, 
INTERNATIONAL JOURNAL OF ACADEMIC RESEARCH IN BUSINESS AND SOCIAL SCIENCES Vol. 8, No. 7, July 2018, E-ISSN: 2222-6990 @ 2018 HRMARS

the ability to include members' suggestions, the ability to decide what to do, to ensure that the roles within the group are understood by the members, the ability to schedule the completion time of work, the desire to make changes, the ability to maintain certainty of performance standards, as well as the ability to require members to follow the standard rules and regulations of the group. Leadership based on task orientation is dominant in providing input for change.

Based on these results, the role played by the board is still not maximal, it will make leader difficult to achieve the group goals and make the leadership ineffective. According to Derue (2011) and Mubarok (2016), leadership based on task orientation dominates leader effectiveness.

The study results shows that, based on the orientation of the relationship, the leadership of the board or the group included in the category normal/adequate with a percentage of $53.25 \%$. The values are composed of the following behaviors: very open and accessible, encouraging members in carrying out procedures, taking small actions to comfort the members of the group, making clear attitudes toward the group, treating the whole group together. In paying attention to member welfare, orientation of leadership relationship of group still less dominant.

Yulk (2005) stated that the relations-oriented leaders will be more attentive, supportive and helpful to their subordinates (members). Based on the result of research, orientation of relation of the farmers group is normal.

\section{Analysis of the Relationship between Leadership with Group Effectiveness}

This study examines the relationship between leadership characteristics based on the nature and leadership based on behavior with the effectiveness of the farmer group. The test used is Spearman correlation test. Spearman correlation test is used because the variables of leadership characteristics based on the nature and behavior are ordinal data while the group effectiveness variable is nominal data. The variables of leadership characteristics based on the properties tested are drive, desire to lead, honesty and integrity, self confidence, intelligence, job relevant knowledge, and extraversion. The variables tested on behavioral leadership characteristics are orientation towards task and relationship orientation. In the group effectiveness variables tested were group productivity, group morale and level of member satisfaction.

This study analyzes the relationship between leadership by nature with group effectiveness ie group productivity, group morale and member satisfaction level (Table 3) and analyzed the relationship between behavioral leadership and group effectiveness (group productivity, group morale and member satisfaction level) (Table 4).

Table 3 shows that the results of Spearman's correlation test indicating there is a relationship between self-confidence with the effectiveness of the group. Confidence is significantly and positive correlated to the group productivity with $r=0.236^{*}$. This means that the more confidence in managing the group, the higher the producvity of the target group. There is still lack of confidence of the leader in mobilizing the members. The lack of confidence is caused by inadequate leadership knowledge in management and communication. The confidence is one of the factors that influence in the effectiveness of communicating (Mubarok \& Priatna, 2016). According to Mubarok and Priatna (2016) leaders need to increase communication and management skills to increase their confidence.

The Spearman correlation test results (Table 3) also indicate a correlation between the job relevant knowledge with the effectiveness of the group. Job relevant knowledge is significantly and positive correlated to the group productivity with $r=0.227^{*}$. This means that the more the job knowledge of manager's have in managing the group, the more productive group will be. Based on the result (Table 1) the leadership level on job relevant knowledge still low (intermediate level), so 
INTERNATIONAL JOURNAL OF ACADEMIC RESEARCH IN BUSINESS AND SOCIAL SCIENCES Vol. 8, No. 7, July 2018, E-ISSN: 2222-6990 @ 2018 HRMARS

the leader is not able to mobilize participation in making the work plan. The lack role played by the board will make leader difficult to achieve the group goals and make the leadership ineffective.

Table 4 Spearman correlation test results shows that there is a relationship between orientation to task with the effectiveness of the farmers' group. The orientation to the task is significantly and positively correlated to the level of member satisfaction with the value of $r=0.236$ *. This means that the higher the orientation to task of the board, the higher the level of satisfaction of the members of the group. The more ability to explain what the member hopes for, the more ability to explain the idea, the more ability to include members' suggestions, the more ability to decide what to do, the more ability to schedule the completion time of work, the more ability to maintain certainty of performance standards, as well as the more ability to require members to follow the standard rules and regulations of the group will increase member satisfaction level. According to Derue (2011) and Mubarok (2016), leadership based on task orientation dominates leader effectiveness.

Spearman correlation test results (Table 4) also show that there is a relationship between orientation to relationship with the effectiveness of farmers' group. The orientation to relationship is very significantly and positive correlated to the level of member satisfaction with the value of $r=$ $0.335^{* *}$. This means that the higher the level of relationship of the board with the members, the satisfaction level of the group members will be higher too. The higher values of the following behaviors: very open and accessible, encouraging members in carrying out procedures, taking small actions to comfort the members of the group, making clear attitudes toward the group, treating the whole group together, the higher the level of satisfaction of the members of the group. Acording to Yunasaf et al. (2008) the high leadership level of the group leader and the high of factors or forces that can encourage the behavior of groups and their members to achieve their goals effectively.

So it can be stated that there is a relationship between leadership with the effectiveness of farmers' group. Findings from previous studies indicated that there is a relationship between leadership and group effectiveness (Zakariyya 2010, Mutmainah \& Sumardjo 2014, Tahitu 2016, Yanti 2015, Anantanyu et al. 2009, Astuti 2010 and Santoso 2008); leadership impact on performance (Mundung et al 2015).

\section{Limitations of the Study}

Findings of the study were beneficial to increasing the group effectiveness. However, findings of the study cannot be generalized because of the small sample size. Further study in the others field will confirm that different culture might influence the grups effectiveness.

\section{Conclusion}

The Spearman correlation test on the relationship between leadership by nature and group effectiveness including group productivity, group morality and level of satisfaction of members of indicate that there is relationship between confidences with the group effectiveness. Confidence is significantly and positively correlated to the group productivity with $r=0.236 *$. This means that the more confidence in managing the group, the higher the producvity of the group. The Spearman correlation test results also indicate a correlation between the job relevant knowledge and the effectiveness of the group. Job relevant knowledge is significantly and positively correlated to the group productivity with $r=0.227^{*}$. This means that the more confidence of leaders in managing the group, the higher group productivity will be. 
INTERNATIONAL JOURNAL OF ACADEMIC RESEARCH IN BUSINESS AND SOCIAL SCIENCES Vol. 8, No. 7, July 2018, E-ISSN: 2222-6990 @ 2018 HRMARS

There is a relationship between orientation to task with the group effectiveness including group productivity, group morale and level of member satisfaction. The orientation to the task is significantly and positively related to the level of member satisfaction with the value of $r=0.236 *$. This means that the higher the orientation to task of the board, the higher the level of satisfaction of the members of the group. Spearman correlation test results also show there is a relationship between orientation to relationship with the effectiveness of farmers' group. The orientation to relationship is very significantly and positively related to the level of member satisfaction with the value of $r=0.335^{* *}$. This means that the higher the level of relationship of the board with its members, the higher the satisfaction level of group members will be.

Thus, there is a relationship between the leadership of the board (based on nature and behavior) with the effectiveness of the farmers' group (based on group productivity, group moral, and the satisfaction level of the member).

\section{References}

Adong A., Mwara F., \& Okoboi G. (2013). What Factors Determine Membership to Farme Group in Uganda? Evidence from the Uganda Cencus of Agriculture 2008/9. Jounal of Sustaible Development. 6(4) Deptan. 2000. Kebijakan Pemberdayaan Kelembagaan Tani. Jakarta: Biro Perencanaan dan KLN Departemen Pertanian.

Anantanyu, S., Sumardjo, Slamet, M., \& Tjitropranoto, P. (2009). "Factors Affecting Farmers' Institutional Effectiveness. Case in Central Java Province" [Faktor-faktor yang mempengaruhi Efektivitas Kelembagaan Petani. Kasus di Provinsi Jawa Tengah]. Jurnal Penyuluhan. Maret 2009 Vol. 5 No.1: 81-91.

Astuti, A.N. (2010). Analisis Efektivitas Kelompok Tani di Kecamatan Gatak Kabupaten Sukohardjo [Analysis of Farmer Group Effectiveness in Gatak District Sukohardjo Regency] (unpublished bachelor essay). Surakarta Sebelas Maret University, Indonesia.

Deptan. (2000). Kebijakan Pemberdayaan Kelembagaan Tani [Policy on Empowerment of Farmer Institution]. Jakarta: Biro Perencanaan dan KLN Departemen Pertanian.

Margono, S. (2001). Paradigma Baru Penyuluhan Pertanian di Era Otonomi Daerah [The New Paradigm of Agricultural Extension in the Era of Regional Autonomy]. Tasikmalaya: Seminar Perhiptani.

Mubarok, M.R. (2016). Kepemimpinan Kontak Tani dan Efektivitas Pokdakan Pembenihan Ikan Lele di Kawasan Minapolitan Kabupaten Bogor [Leadership of Farmer Group and Effectiveness of the Farmer Group of Catfish Breeding in Minapolitan Area of Bogor Regency] (unpublished master thesis. Bogor Agriculture University, Indonesia,

Mubarok, M. R., \& Priatna, W.B. (2016). Hubungan Gaya Kepemimpinan Kontak Tani terhadap Persepsi Kinerja Kelompoktani Ikan Lele di Desa Babakan, Ciseeng, Kabupaten Bogor [Relationship of Leadership Style of Farmers Group to Performance Perception of Group of Catfish Fish at Babakan Village, Ciseeng, Regency of Bogor]. Jurnal Forum Agribisnis Vol 6, No 1: 2016 Mar.

Mundung, J., Lengkong, F. D., \& Tulusan, F. (2015). Pengaruh Kepemimpinan terhadap efektifitas Kerja Pegawai pada Kelurahan Bahu [The Effect of Leadership on Employee Effectiveness in the Village of Bahu Sub District]. Jurnal Administrasi Publik.Vol 2, No.30.

Mutmainah, R., \& Sumardjo. (2014). Peran Kepemimpinan Kelompok Tani dan Efektivitas Pemberdayaan Petani [Role of Farmer Group Leadership and Farmer Empowerment Effectiveness] Sodality: Jurnal Sosiologi Pedesaan. Desember 2014, hlm: 182-199. 
INTERNATIONAL JOURNAL OF ACADEMIC RESEARCH IN BUSINESS AND SOCIAL SCIENCES Vol. 8, No. 7, July 2018, E-ISSN: 2222-6990 @ 2018 HRMARS

Prasetyo, S. H., \& Falentino, R. (2015). Hubungan Perilaku Pemimpin dengan Keaktifan Anggota Kelompoktani di Desa Sukanagalih Kecamatan Pacet Kabupaten Cianjur [Relationship of Leaders' Behavior with Activity of Group Members in Sukanagalih Village, Pacet Sub-District, Cianjur District]. Jurnal Agroscience Volume 5 N0.2: Juli - Desember 2015.

Santoso, A. (2008). Analisis Efektivitas Kelompok Tani Hamparan di Kecamatan Delanggu Kabupaten Klaten [Effectiveness Analysis of Farmer Group in Delanggu District of Klaten Regency] (unpublished bachelor essay). Surakarta Sebelas Maret University, Indonesia.

Siddiq, D. (2014). Analisis Hubungan Gaya Kepemimpinan dengan Kinerja Kelompoktani. Studi Kasus Kelompoktani Ternak Karya Sejahtera, Desa Karyawangi, Kecamatan Parongpong, Kabupaten Bandung Barat [Relationship Analysis of Leadership Style with Group Performance. Case Study of Livestock Farmers Work Sejahtera, Village Workwangi, Parongpong District, West Bandung Regency] (unpublished bachelor essay). Bogor Agriculture University, Indonesia.

Tahitu, M. E. (2016). Hubungan Kepemimpinan Ketua Kelompok dengan Efektivitas Kelompok Tani di desa Cikarawang Kecamatan Dramaga Kabupaten Bogor [Leadership of the Leader Group Relations with Farmer Group Effectiveness in the village Cikarawang Dramaga District, Bogor Regency]. Agrilan Jurnal Agribisnis Kepulauan. Volume 4 No.3 Oktober 2016.

Yanti, R. D. (2015). Dinamika Kelompok Perkumpulan Petani Pemakai Air di Lahan Rawa Lebak [The Dynamics of Group of Water User Farmers in Rawa Land Lebak Regency]. SEPA. Vol.11 No.2 Februari 2015:235-248.

Yulk, G. (2005). Kepemimpinan dalam Organisasi. Edisi Kelima [Leadership in Organizations]. Jakarta: PT.Indeks Kelompok Gramedia.

Yunasaf, U. (1997). Perilaku Kepemimpinan Kontak Tani menurut Anggota Kelompoktani. Kasus pada Kelompoktani Ternak Ayam Buras di Kabupaten Ciamis [Leadership Behavior of Group Leaders by Farmer Group Members. The case of the Kampong Chicken Farmer Group in Ciamis Regency] (unpublished master thesis). Bogor Agriculture University, Indonesia.

Yunasaf, U. (2007). Kepemimpinan Ketua Kelompok dan Hubungannya dengan Keefektifan Kelompok. Kasus pada Kelompoktani Ternak Sapi Perah di Wilayah KerjaKoperasi Serba Usaha Tandangsari Sumedang [Leadership of Group Leaders and Their Relation to Group Effectiveness. Case in Dairy Farmer Group in Work Area of Multipurpose Cooperative Tandangsari Sumedang]. Jurnal IImu Ternak Desember 2007, Vol. 7, No.2, 179-185

Yunasaf, U., Ginting, B., Slamet, M., \& Tjitropranoto, P. 2008. Peran Kelompok Peternak dalam Mengembangkan Keberdayaan Peternak Sapi Perah. Kasus Kabupaten Bandung [The Role of Farmers Group in Developing the Empowerment of Dairy Cattle Farmers. Bandung Regency Case]. Jurnal Penyuluhan. September 2008, Vol.4 No. 2.

Zakariyya, M. D. (2010). Hubungan Kepemimpinan Ketua Kelompok Tani dengan efektivitas Kelompok Tani di Kecamatan Pacitan, Kabupaten Pacitan [Leadership Relationship of Farmer Group Leader with Farmer Group effectiveness in Pacitan District, Pacitan Regency] (unpublished bachelor essay). Surakarta Sebelas Maret University. 